Thorax (1958), 13, 286.

\title{
OSSIFYING BRONCHIAL ADENOMA
}

\author{
BY \\ SIR CLEMENT PRICE THOMAS AND A. D. MORGAN \\ From the John Burford Carlill Pathological Laboratories, Westminster School of Medicine, London
}

(RECEIVED FOR PUBLICATION AUGUST 11, 1958)

In 1938 Womack and Graham described the presence of bone and cartilage in bronchial adenomata, and quoted this finding to support their theory that such tumours are "mixed" in origin, arising from undeveloped bronchial buds, and containing both mesodermal and entodermal elements.

These views were challenged by Mallory (1941), who regarded the cartilaginous elements as part of the original bronchial wall, and the bone as a metaplasia of the fibrous stroma in the adenoma. Moersch, Tinney, and McDonald (1945) suggested that the bone might be derived directly from bronchial cartilage.

To-day it is generally conceded that the bronchial adenoma is a benign epithelial tumour of mucous glands, with a cylindromatous variant of low-grade malignancy, but the "mixed tumour" theory still has occasional adherents, e.g., Santy, Galy, and Duprez (1951). The occasional presence of bone in the growth is usually attributed to metaplasia of the stroma (Willis, 1953).

The frequency with which ossification occurs in bronchial adenomata is difficult to assess. Womack and Graham found it in five of their 11 cases, Holley (1946) in eight out of 39 cases, and Sano and Meade (1947) in three out of five cases. On the other hand Foster-Carter (1941) failed to find bone in a study of 22 adenomata remoyed at the Brompton Hospital; nor does he appear to have encountered reference to ossification in his careful review of 47 other cases in the literature. Similarly Stout (1943) did not observe bone in any of his 20 cases.

Between the years 1939 and 1958, 63 cases of bronchial adenoma have been treated by resection by one of us (C. P. T.). Widespread ossification of the type dealt with in this paper has been specifically mentioned by the pathologist in only three cases, which are recorded below.

\section{Case Histories}

CASE 1.-A man aged 47 complained of cough and dyspnoea on exertion following unresolved pneu- monia of the right lower lobe six months earlier. On examination he looked fit. There was diminished air entry over the right base but no adventitious sounds. Bronchoscopy revealed a nodular growth of the right main bronchus, extending above the middle lobe orifice. A right pneumonectomy was performed. Convalescence was uninterrupted.

Pathology.-The right main bronchus was blocked by a rounded tumour of bony consistency, $2.2 \mathrm{~cm}$. in diameter. The ossified portion, constituting most of its bulk, lay outside the line of the bronchial cartilages. The polypoid ingrowth blocking the lumen represented less than a tenth of the whole and was quite soft. The bronchi beyond the obstruction were distended with clear mucus.

Microscopically the tumour was a fairly typical adenoma with an alveolar pattern. A cross-section of the tumour at right angles to the bronchial axis is shown in Fig. 1. The intrabronchial part of the growth is purely cellular and covered by intact mucosal epithelium. The ossified core has a mature cancellous structure, and embedded in its centre is a plaque of cartilage which, from its shape, size, and position, looks like one of the original bronchial plates which has been engulfed by tumour cells. The bony trabeculae are closely applied to the cartilage, without a visible perichondrium. Towards the centre of the ossified zone the interstices contain fat and a little haemopoietic tissue (Fig. 2): farther out they are filled with tumour tissue. The whole growth is surrounded by a thick, fibrous capsule which probably represents the original peribronchial connective tissue. The adjacent lymph nodes are not invaded.

A curious feature is a small focus of ossification at the margin of one of the bronchial cartilages lying to one side of the main growth (Fig. 3). At this point the bony process is surrounded by a thin layer of tumour cells, an observation which first suggested to us that bronchial cartilage might be a factor in the process of ossification.

CASE 2.-A man aged 54 complained of recent deterioration in health. Twenty years earlier, following several attacks of right basal pneumonia, he was found to have an adenoma obstructing the right lower and middle bronchi. After treatment with radon seeds the tumour became smaller and the bronchi became patent, although there was some residual bronchiectasis. 


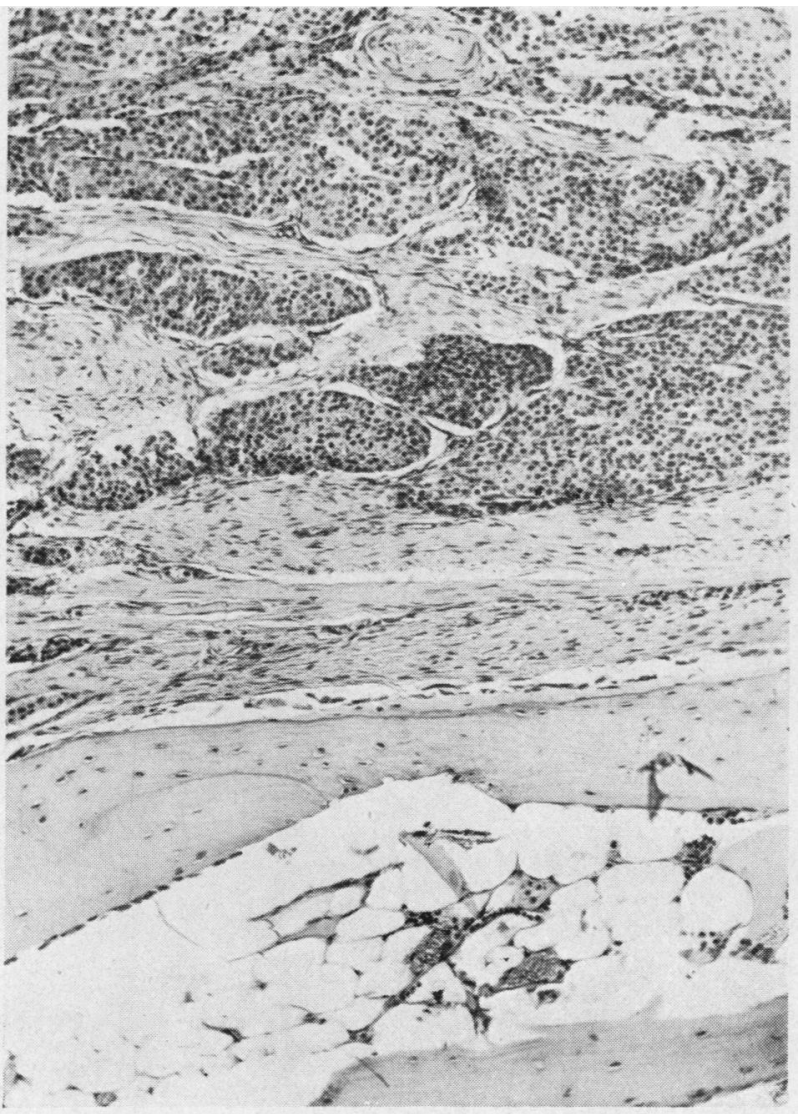

Fig. 2

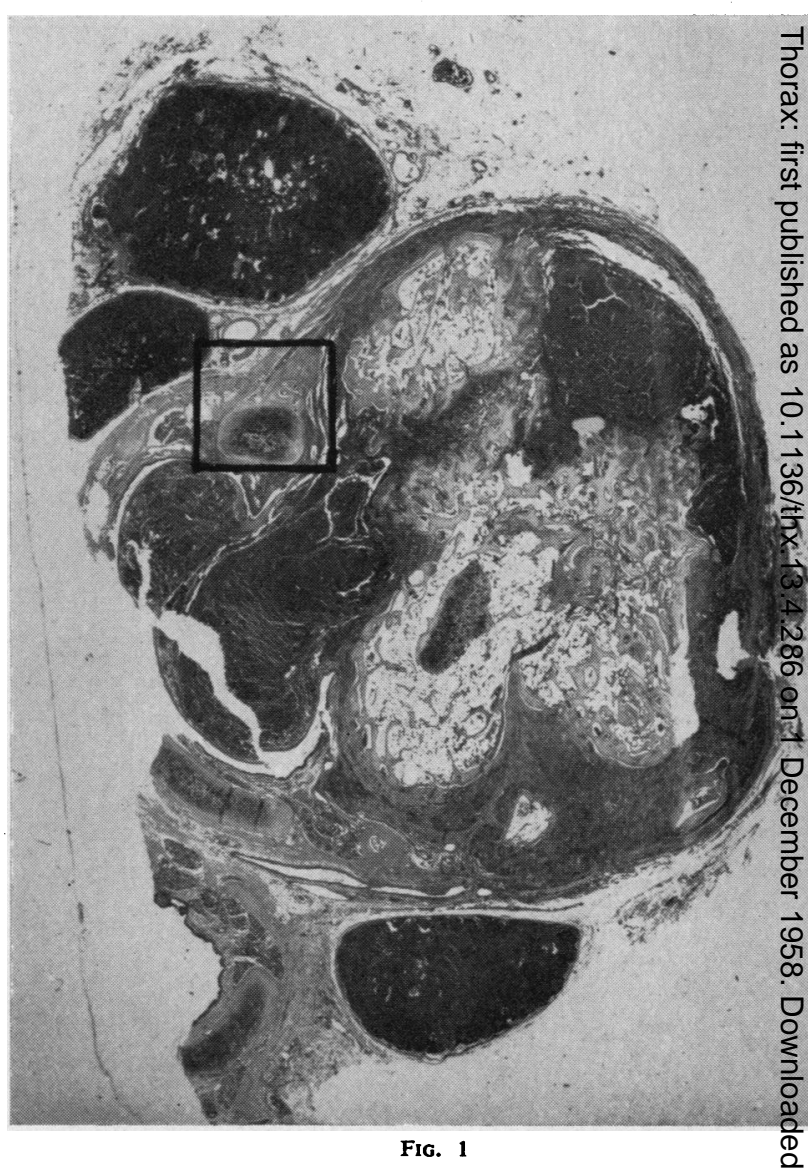

Fig. 1.-Case 1. Transverse section of tumour showing cellular par occluding bronchus (left), and remains of bronchial cartilage in centro of osseous part. Haematoxylin-eosin $\times$ 4.5.

Fig. 2.-Case 1. Mature bone in stroma of tumour. Haematoxylin eosin $\times 75$

FIG. 3.-Case 1. Ossification from bronchial cartilage lying outside the main tumour (see inset, Fig. 1). Haematoxylin-eosin $\times 35$.

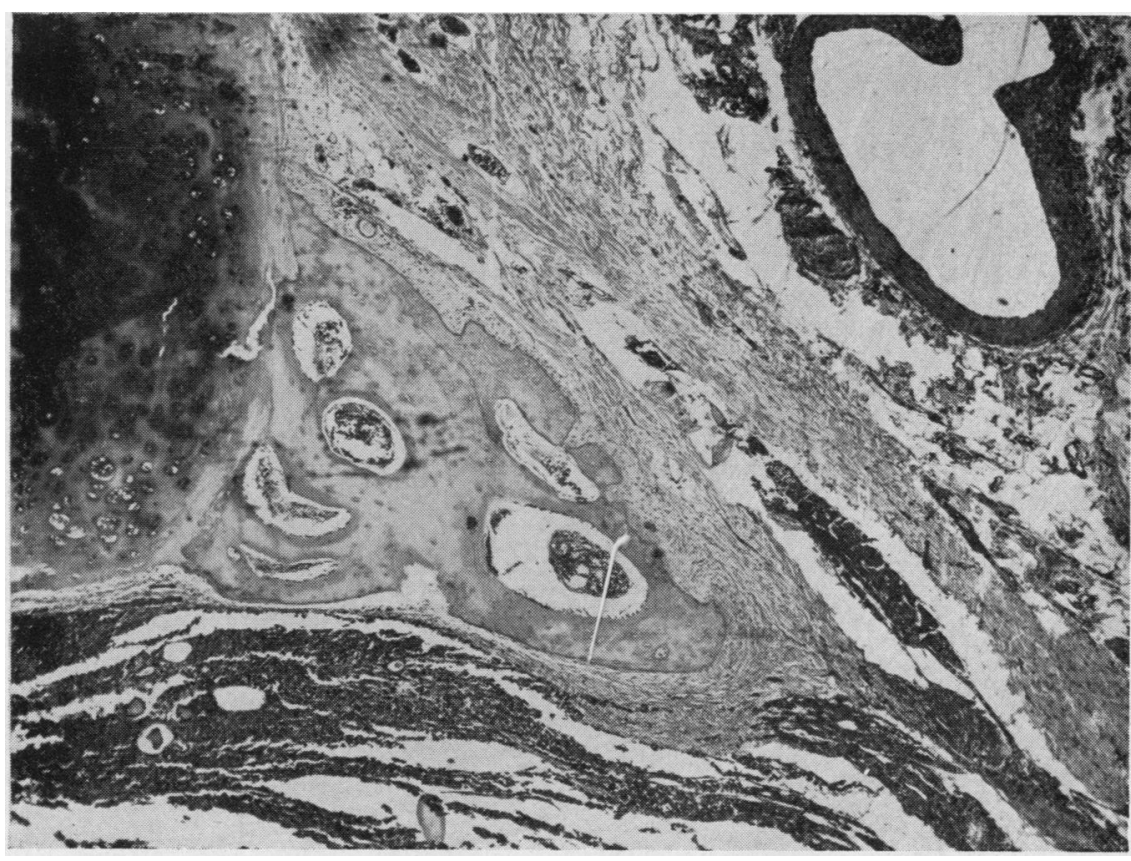

Fig. 3 


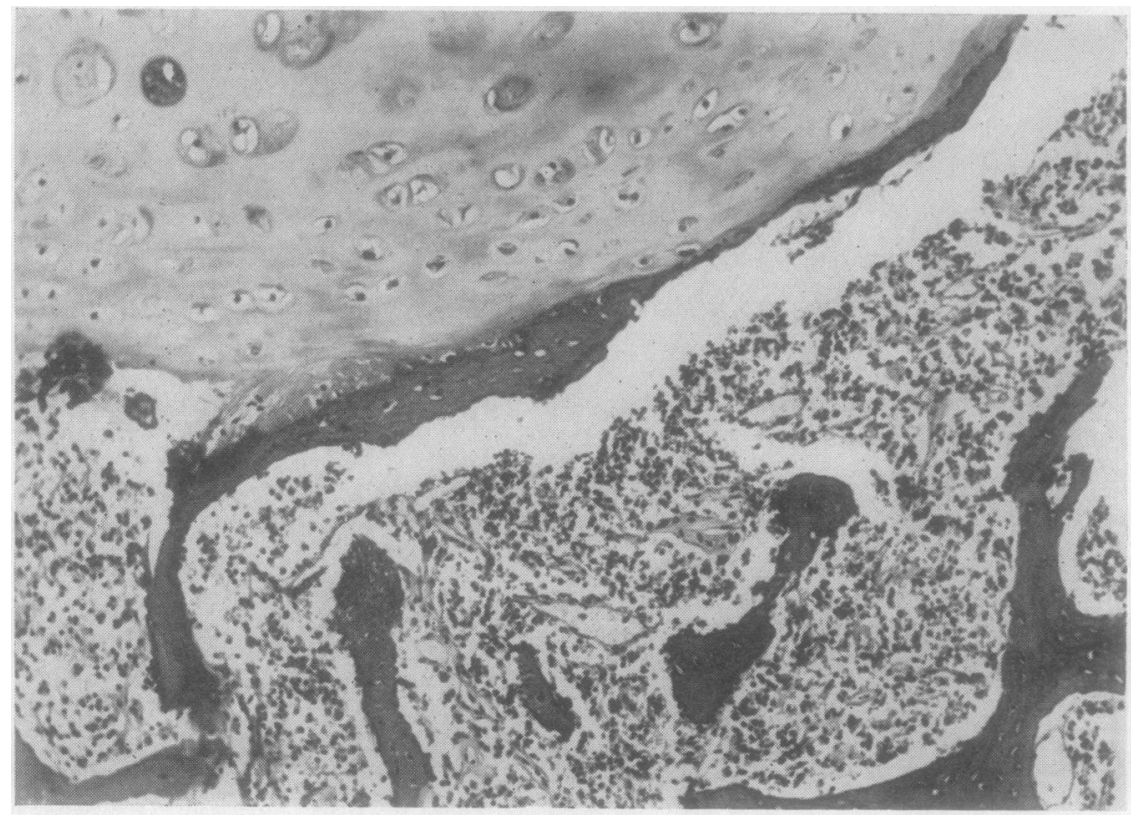

Fro. 4

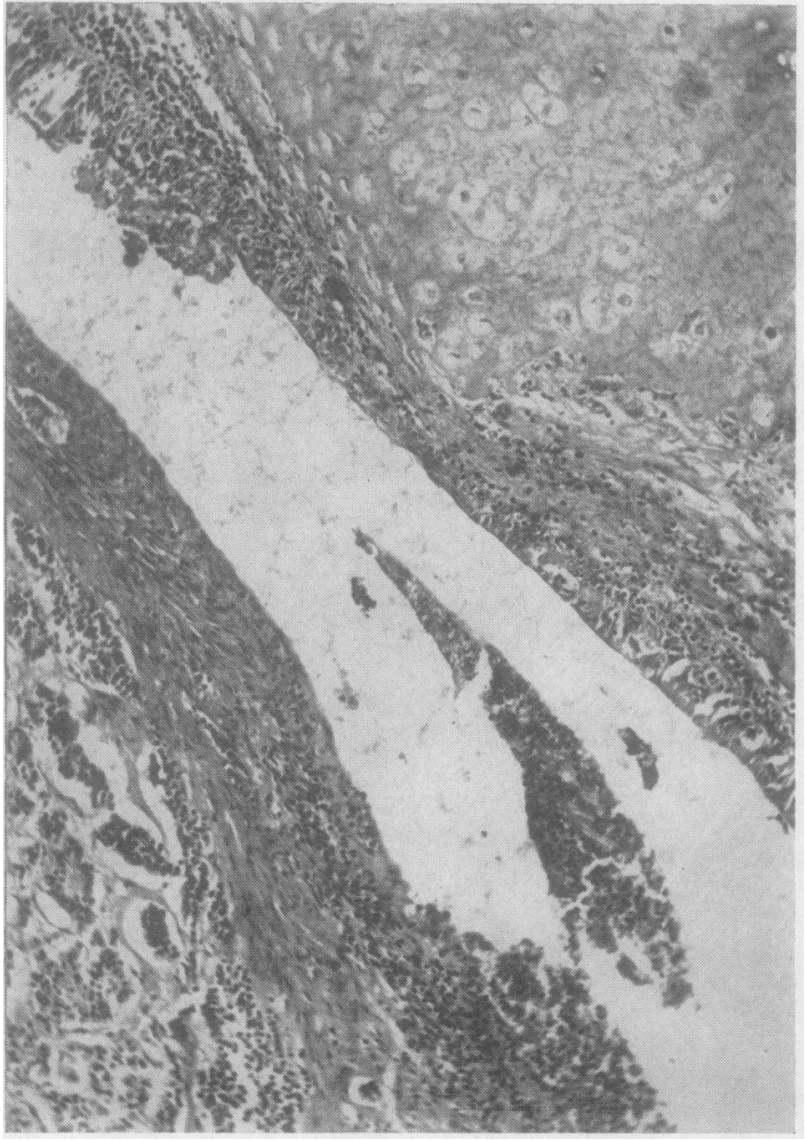

Fig. 5

FIG. 4.-Case 2. Ossification at periphery of bronchial cartilage, continuous with bony trabeculae in tumour. Haematoxylineosin $\times 75$.

FIG. 5.-Case 2. Degeneration of bronchial cartilage outside tumour (lower left) but compressed by it. Haematoxylin-eosin $\times 65$.

Fig. 6.-Case 2. Other end of same bronchial cartilage, replaced by bone although outside tumour, which is seen occluding bronchus (right). Haematoxylin-eosin $\times 30$

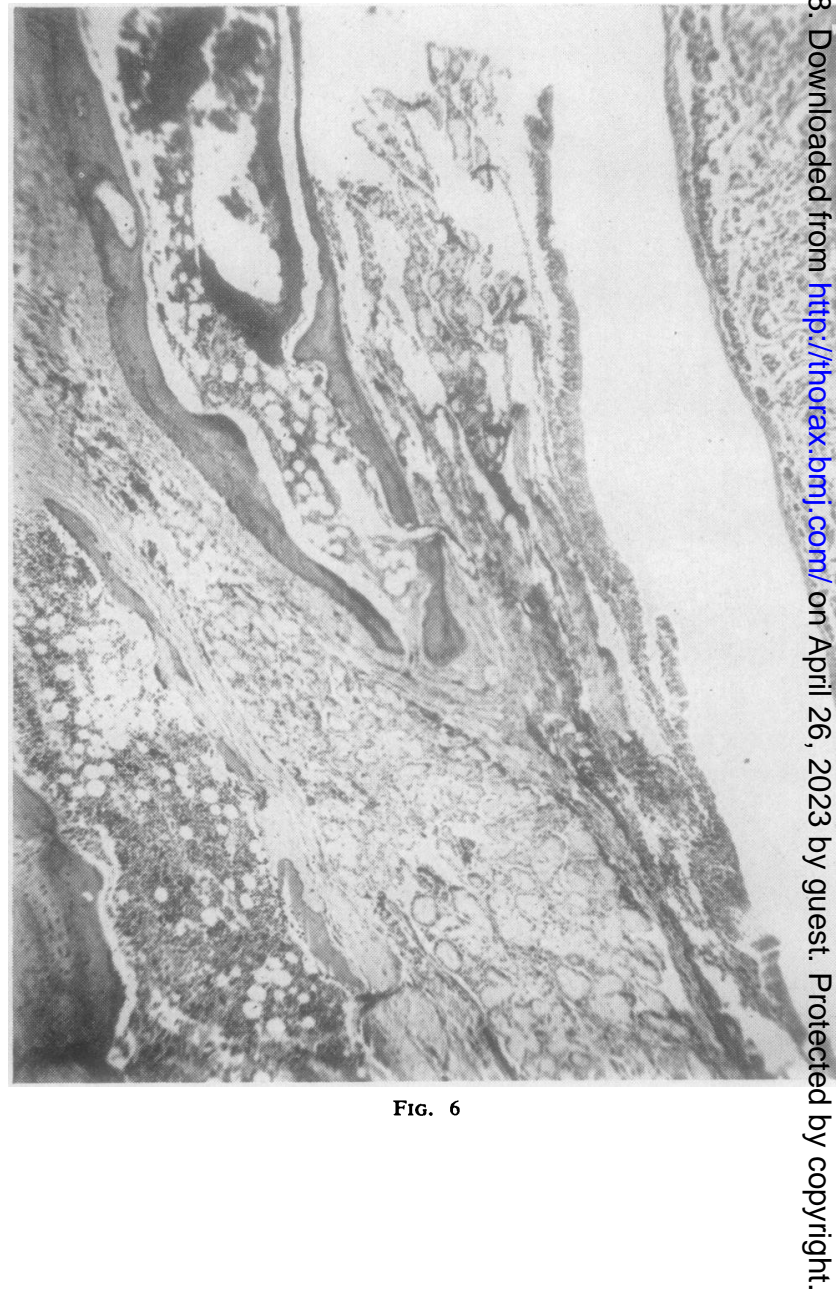


He continued to have attacks of pneumonia every other year, and one year before his operation he was found to be suffering from pulmonary tuberculosis, confirmed by sputum examination. After nine months' treatment with streptomycin and I.N.A.H. he improved sufficiently to allow a right pleuro-pneumonectomy to be performed. Convalescence was stormy, but he was fit for discharge 15 weeks later.

Pathology.-In the right lower lobe bronchus, at its division into segmental branches, was a tumour with a bossed intrabronchial projection which completely occluded the bronchus and expanded into the lung in a lobulated fashion over an area of $4 \times 2 \mathrm{~cm}$., the greatest extension being in the direction of the basal segmental bronchi. Beyond the obstruction the lung showed bronchiectasis and collapse.

Microscopically the tumour was an adenoma with a trabecular pattern. As in Case 1, the growth has engulfed several bronchial cartilages. Some of these have retained their perichondrium ; others show ossification at the periphery, with extension of bony

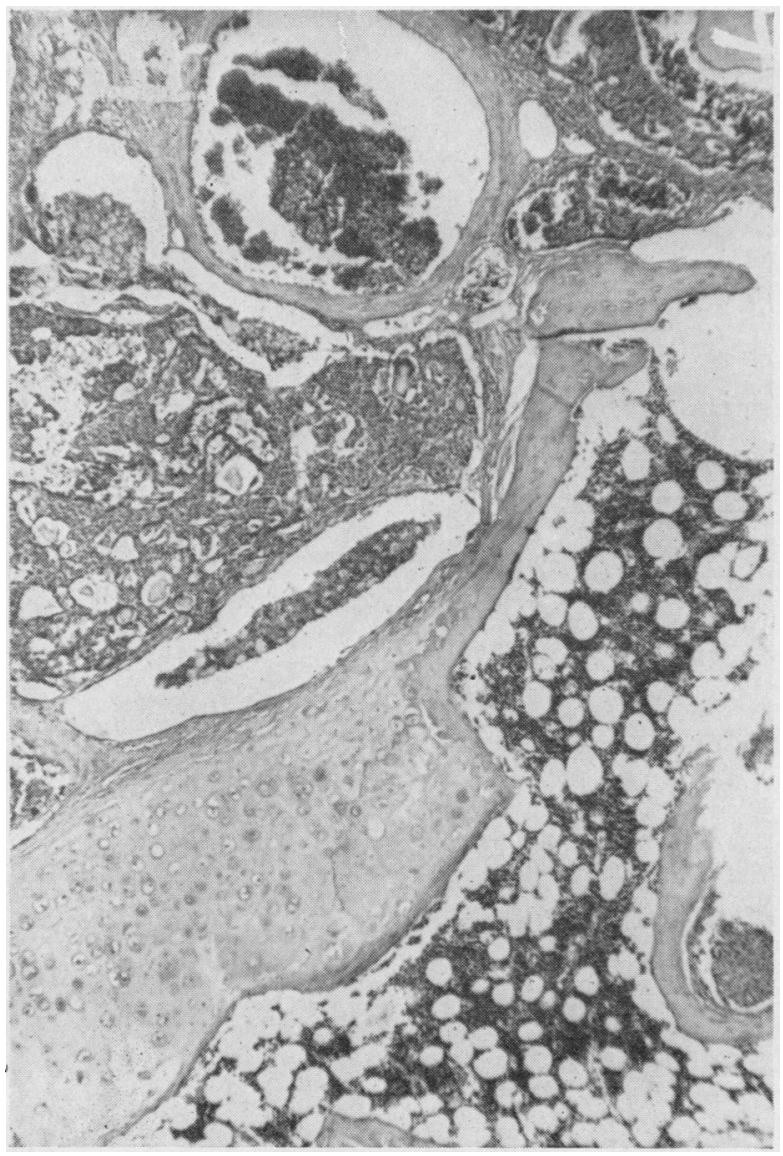

Fig. 7.-Case 3. Bronchial cartilage within the tumour, showing peripheral ossification (centre) and haemopoietic tissue (right). Haematoxylin-eosin $\times 40$. trabeculae into the tumour (Fig. 4). In general, there is less bone formation than in the previous case. The cartilage buttressing the bronchial wall opposite to the tumour shows degeneration of its inner aspect, apparently due to pressure and infection from the ulcerated surface of the growth (Fig. 5). Although this cartilage lies completely outside the tumour, it is replaced at one end by bone (Fig. 6).

CASE 3.-A woman aged 60 was found to have a shadow in the left lower lobe on mass radiography. Her only symptoms had been an attack of bronchitis and some pain in the left chest, but, as a radiograph one year later showed an increase in the size of the shadow, she was admitted to hospital.

On examination she looked healthy, and there were no abnormal physical signs in the chest. Tomography of the shadow in the chest showed that it was calcified. Bronchoscopy showed no abnormality. At operation a mass was felt in the subapical region of the left lower lobe, of bony consistency. The lobe was resected and the patient made a good recovery.

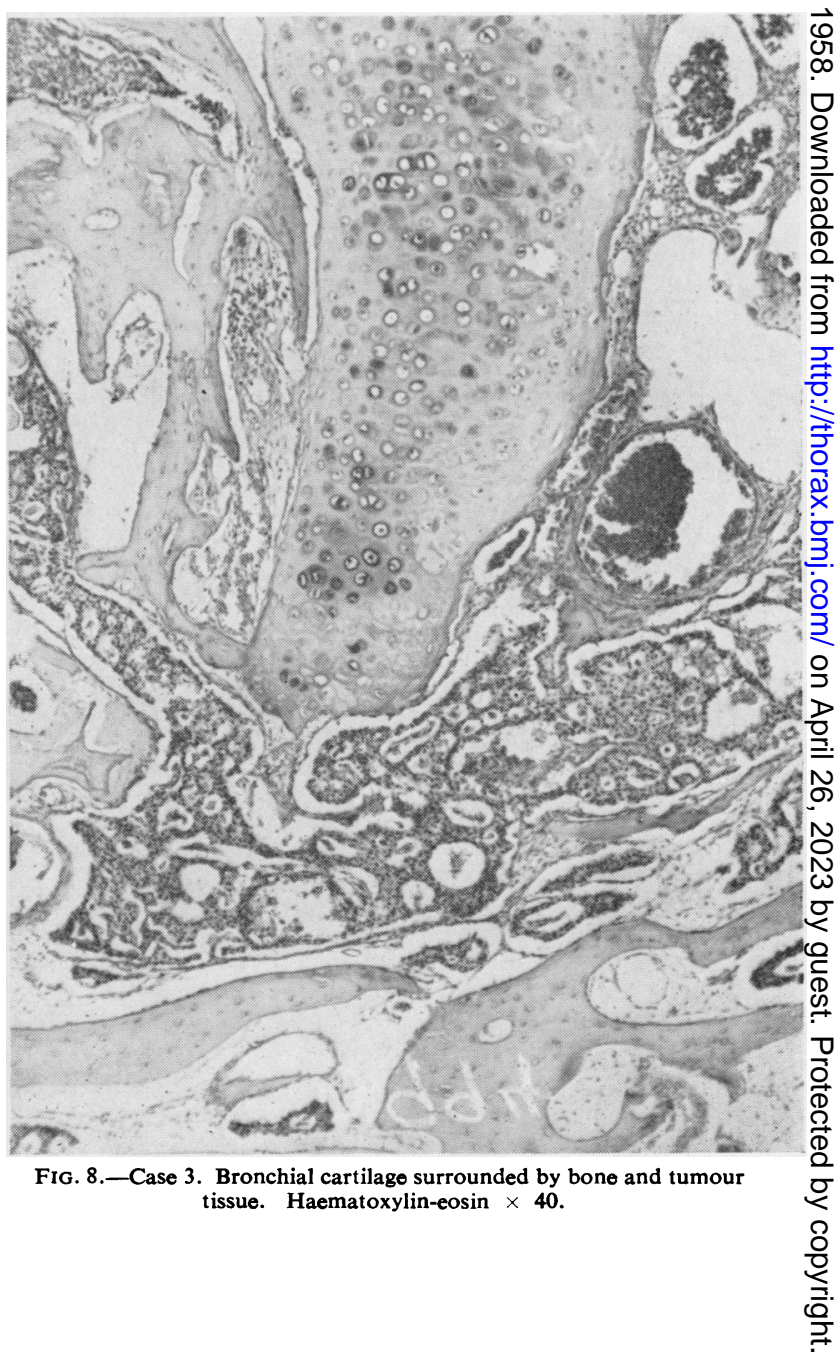


Pathology.-The posterior basal segmental bronchus was blocked by a dumb-bell-shaped tumour $4 \times 2.5 \mathrm{~cm}$. in size. Much of the growth was ossified, and the lung distal to it showed mild bronchiectasis and early fibrosis.

Microscopically the tumour was an adenoma with a trabecular pattern. Buried in the growth are two or three cartilaginous plaques, the size and shape of bronchial cartilages. Intimately connected with the cartilage, and extending into the tumour, are numerous bony trabeculae, between which lie islands of tumour cells or haemopoietic tissue (Figs. 7 and 8).

\section{Discussion}

We have already said that Mallory (1941) regarded ossification in bronchial adenomata as a metaplasia of the stroma of the growth. The concept of osseous metaplasia in the stroma of tumours was not new, and Willis $(1952,1953)$ has quoted a number of instances from the earlier literature. These are summarized in Table $I$. That the bone-forming properties are peculiar to the tumour rather than to environmental factors is suggested by the fact that not only, in five other instances, did ossification occur in a local recurrence after removal of the primary growth, but in a further seven bone was present in the stroma of distant metastases (Tables II and III).

TABLE I

OSSIFICATION IN PRIMARY TUMOUR ONLY (EXCLUDING BRONCHIAL ADENOMATA)

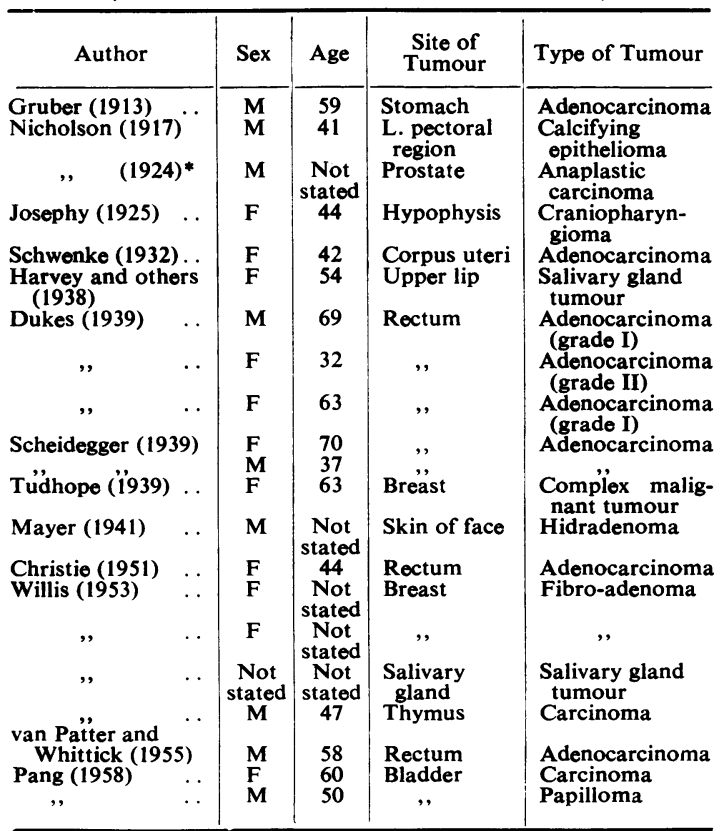

* In the same paper Nicholson records the presence of cartilage in the stroma of an adenocarcinoma of the corpus uteri.
In addition to our own three, we have been able to find 17 other case reports of ossifying bronchial adenoma in the literature (Table IV). One is struck by the disparity between the rarity

TABLE II

OSSIFICATION IN LOCAL RECURRENCE

\begin{tabular}{|c|c|c|c|c|c|}
\hline Author & Sex & Age & $\begin{array}{l}\text { Site of } \\
\text { Primary } \\
\text { Tumour }\end{array}$ & $\begin{array}{c}\text { Site of } \\
\text { Recurrence }\end{array}$ & $\begin{array}{l}\text { Type of } \\
\text { Tumour }\end{array}$ \\
\hline $\begin{array}{l}\text { Reich (1933) } \\
\text { Clark (1935) }\end{array}$ & $\begin{array}{l}\mathbf{F} \\
\mathbf{F}\end{array}$ & $\begin{array}{l}52 \\
51\end{array}$ & $\begin{array}{l}\text { Uterus } \\
\text { Pelvic } \\
\text { colon }\end{array}$ & $\begin{array}{l}\text { Pelvis } \\
\text { Abdominal } \\
\text { scar }\end{array}$ & $\begin{array}{l}\text { Carcinoma } \\
\text { Adenocarcinoma }\end{array}$ \\
\hline Dukes (1939) & $\mathbf{M}$ & 53 & Rectum & Pelvis & (grade I) \\
\hline $\begin{array}{l}\text { Senturia and } \\
\text { others }(1948)\end{array}$ & $\mathbf{M}$ & 55 & , & ," & Adenocarcinoma \\
\hline Christie(1951) & $\mathbf{F}$ & 43 & ,", & ,', & , \\
\hline
\end{tabular}

TABLE III

OSSIFICATION IN DISTANT METASTASES

\begin{tabular}{|c|c|c|c|c|c|}
\hline Author & Sex & Age & $\begin{array}{l}\text { Site of } \\
\text { Primary } \\
\text { Tumour }\end{array}$ & $\begin{array}{c}\text { Site of } \\
\text { Bony } \\
\text { Metastases }\end{array}$ & $\begin{array}{l}\text { Type of } \\
\text { Tumour }\end{array}$ \\
\hline Schmorl & $\mathbf{M}$ & 66 & Prostate & Lungs & Carcinoma \\
\hline $\begin{array}{l}\text { Laubmann } \\
(1932)\end{array}$ & $\mathbf{M}$ & 65 & Stomach & ," & $\begin{array}{l}\text { Anaplastic scir- } \\
\text { rhous carci- }\end{array}$ \\
\hline Micseh (1933) & $\mathbf{F}$ & 55 & $\begin{array}{l}\text { Gall } \\
\text { bladder }\end{array}$ & $\begin{array}{l}\text { Lungs, } \\
\text { liver, } \\
\text { lymph } \\
\text { nodes }\end{array}$ & Carcinoma \\
\hline $\begin{array}{r}\text { Christie } \\
\text { (1951) }\end{array}$ & $\mathbf{M}$ & 48 & Colon & $\begin{array}{l}\text { Rectus } \\
\text { abdominis }\end{array}$ & Adenocarcinoma \\
\hline $\begin{array}{l}\text { Willis (1953) } \\
\text { van Patter and }\end{array}$ & $\begin{array}{l}\mathbf{F} \\
\mathbf{M}\end{array}$ & $\begin{array}{l}24 \\
43\end{array}$ & $\begin{array}{l}\text { Trachea } \\
\text { Rectum }\end{array}$ & $\begin{array}{l}\text { Skin } \\
\text { Lung }\end{array}$ & $\begin{array}{l}\text { Cylindroma* } \\
\text { Adenocarcinoma }\end{array}$ \\
\hline , , , , & $\mathbf{M}$ & 46 & Colon & $\begin{array}{l}\text { Abdominal } \\
\text { wall }\end{array}$ & , \\
\hline
\end{tabular}

* cf. Belsey and Valentine (1951).

TABLE IV

OSSIFICATION IN BRONCHIAL ADENOMATA

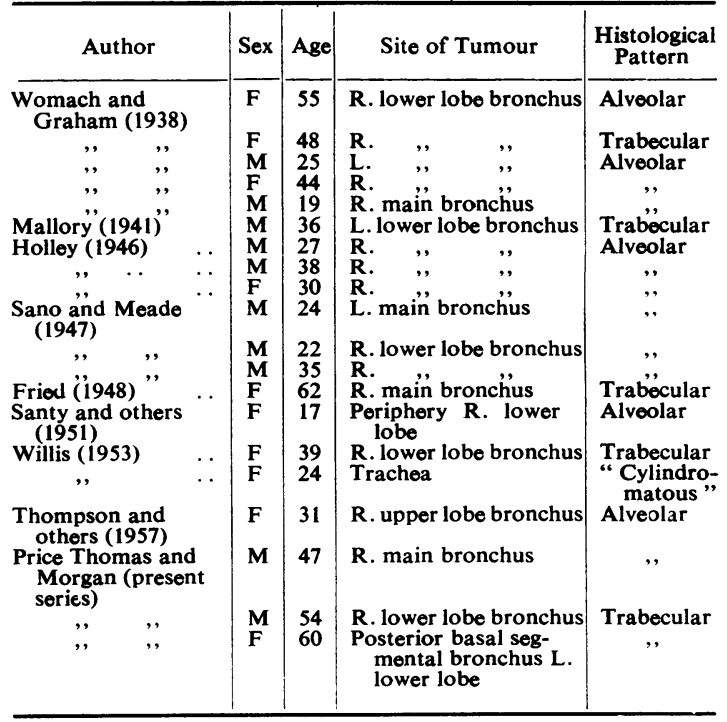




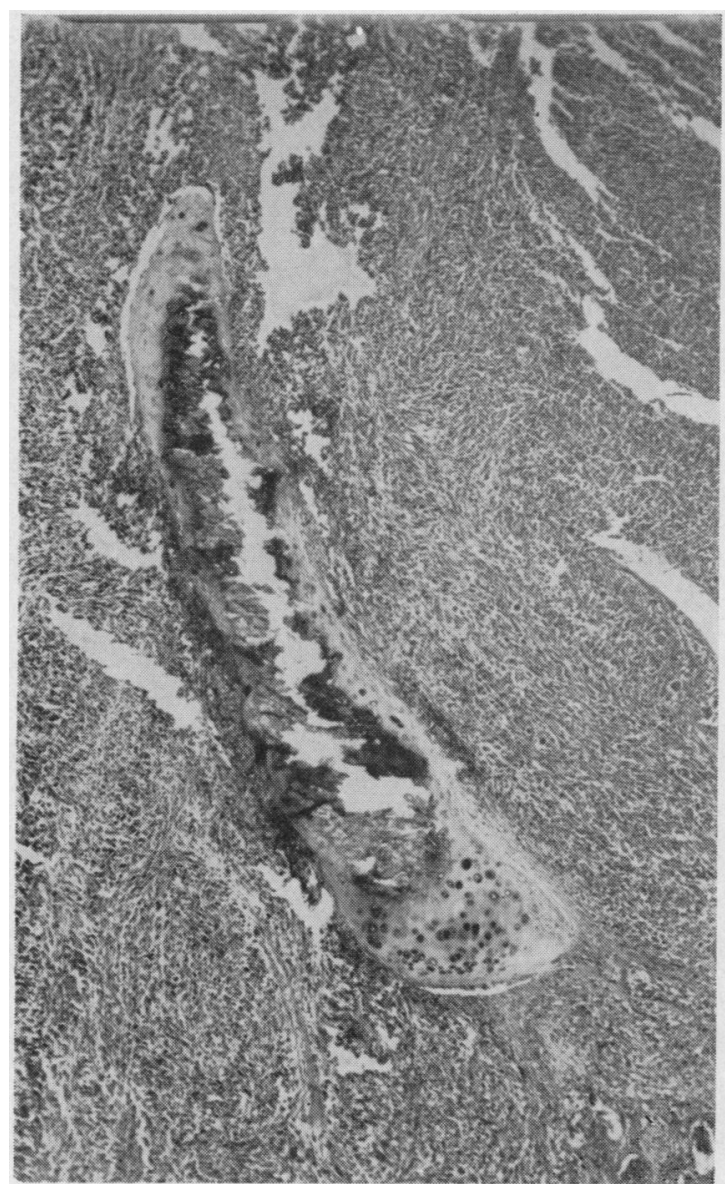

Fig. 9.-Pulmonary metastasis from thyroid carcinoma. Bronchial cartilage undergoing necrosis and calcification. Haematoxylin$\operatorname{cosin} \times 35$.

of the bronchial adenoma (as compared with tumours of the gastro-intestinal tract, breast, etc.) and the relative frequency with which ossification of its stroma has been recorded. Unless there are multiple causes of stromal ossification in tumours, there must be something about the bronchial adenoma which particularly predisposes to bone formation. Consequently we have given some consideration to the conditions under which physiological and pathological ossification can occur.

There are two main theories of osteogenesis. The classical theory of the nineteenth century was that bone was laid down exclusively by osteoblasts, specific cells with a specific function, both in the embryo and the adult. In 1928 Leriche and Policard advanced the persuasive argument that bone, cartilage, tendon, or adipose tissue all belong to the same family of connecting or sup- porting substances, derived from the primitive mesenchyme. Given appropriate conditions, any connective cells are capable of undergoing modification to form bone.

These conditions would appear to include tissue necrosis and the presence of calcium. Ossification may be preceded by cartilage, as in the growth of long bones, but the cartilage, before it is replaced by bone, first becomes calcified and then absorbed. "Osteoblasts" are no more than modified connective tissue cells from the nearest available source, in this case the periosteum. Leriche and Policard described several experiments in which transplants of cartilage to soft tissue are followed by death of the cartilage and liberation of calcium in the vicinity, stimulating the connective tissue cells of the host to form bone.

These same authors, in support of their theory, argued that heterotopic bone formation, in old haematomas, laparotomy scars, artery walls, tumours, etc., took place well away from periosteum and "osteoblasts." In all of these examples they found evidence of local tissue necrosis followed by calcification and ultimately by bone formation.

However, physiological osteogenesis is effected mainly through the medium of cartilage, and it is our belief that the relative frequency of ossification in bronchial adenomata is, in part at least, due to the incorporation of cartilage in the tumour. This latter phenomenon has been attributed to the origin of the growth in mucous glands situated deeply in the bronchial wall, a variant of adenoma called " intramural" by Kramer and Som (1935), although well illustrated in several other papers, e.g., Wessler and Rabin (1932) and Foster-Carter (1941). We agree with Mallory (1941) and Holley (1946) that all cartilage in bronchial adenomas is of physiological origin, and not evidence of a " mixed" tumour.

It is one of the conditions of cartilaginous ossification that the deposition of bone is preceded by necrosis and calcification of the cartilage. The causes of necrosis and calcification of bronchial cartilage would appear to be multiple. Cartilage, being avascular, is nourished by the surrounding tissue fluids. It is highly likely that nutrition is interfered with when the bronchial cartilages are engulfed by any tumour, benign or malignant (Fig. 9).

To test this proposition we re-examined 10 "non-ossifying" bronchial adenomata in which cartilage was included in the growth. Four of these were "cylindromatous," and presumably more rapidly growing (Kramer and Som, 1939; 


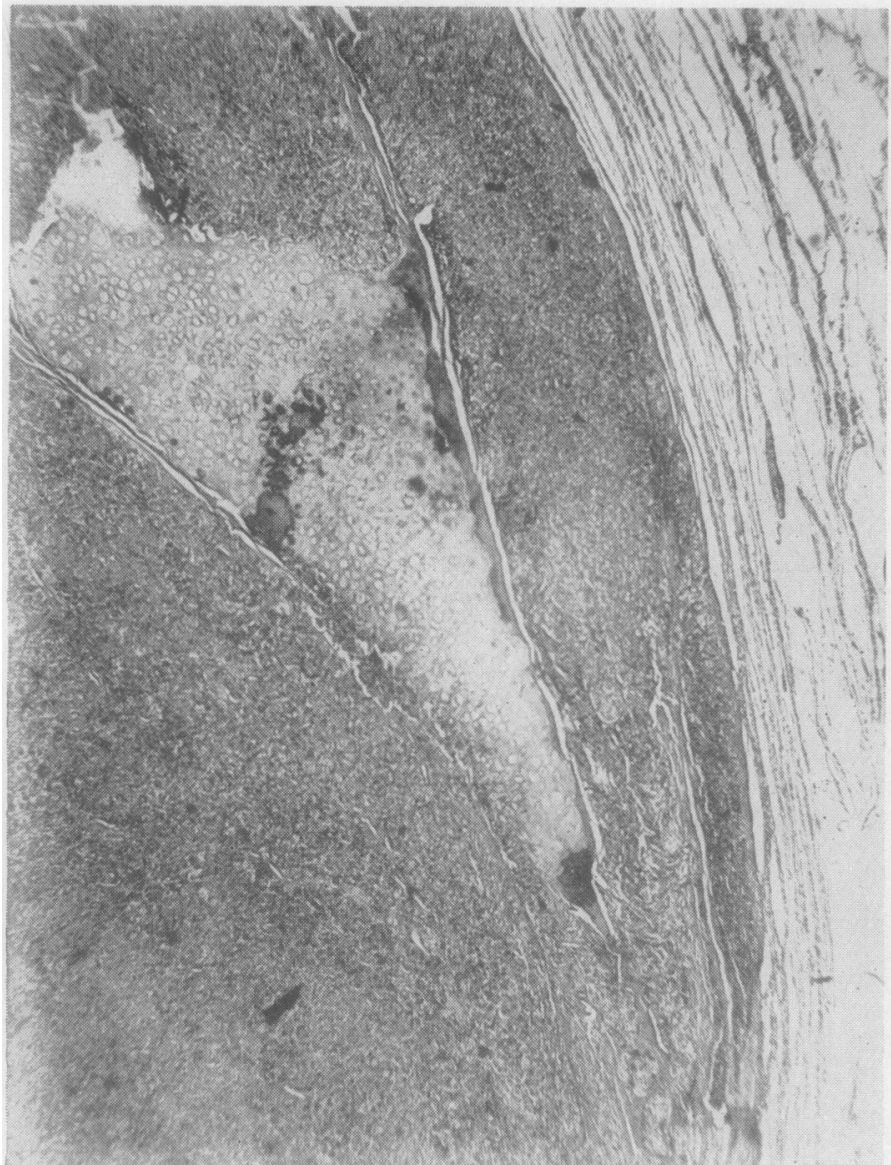

FIG. 10.-Non-ossifying bronchial adenoma. Bronchial cartilage showing loss of perichondrium, erosion, and patchy calcification. Haematoyxlin-eosin $\times 25$.

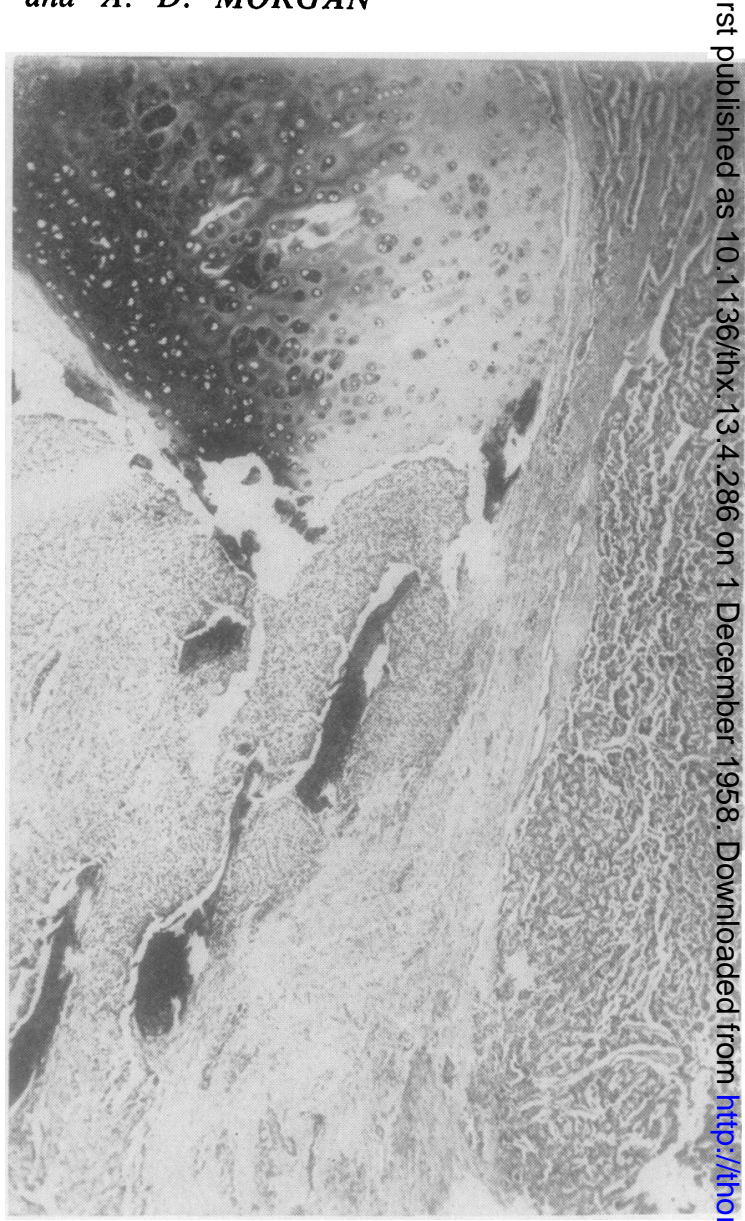

FIG. 11.-Non-ossifying bronchial adenoma. Destruction of cartilage and calcification. Haematoxylin-eosin $\times 35$.
Belsey and Valentine, 1951). All of these showed erosion of the periphery of the cartilage by tumour cells, but no calcification. The other six were of the more slowly growing type with an alveolar or trabecular pattern. All of them showed erosion of the perichondrium, and three showed destruction and calcification of cartilage (Figs. 10, 11). One of them, indeed, displayed, in addition to calcification round the margin of the cartilage, early bone formation with extension into the surrounding stroma (Fig. 12). Here, presumably, the bone-forming elements are derived from the actively proliferating connective tissue cells in the stroma of the adenoma and not directly from cartilage, as Moersch and others (1945) seem to suggest.

There are, of course, other causes of necrosis and calcification of cartilage, notably pressure of the intrabronchial portion of the tumour on the surrounding bronchial wall. Infection may also be a factor (Fig. 5). This may explain the tendency of the cartilages to form bone outside the main body of the tumour (Figs. 3, 6).

Destruction of cartilage, however, is not the whole story, otherwise ossification would be the rule in bronchial adenomata; nor does this factor account for the tumours in Tables I and II, where there was no cartilage; and particularly in Table III, where the metastases also contained bone. Willis's second case (Table IV) was a cylindromatous tumour of the trachea which later produced a bone-forming metastasis below the skin. In the ossifying adenoma of Thompson, Bosman, and Dumm (1957) there was a metastasis to a bronchial lymph node which did not, however, contain bone.

Tissue necrosis is considered an important factor in the heterotopic bone formation of old haematomas, laparotomy scars, degenerate arteries, etc., but necrosis is so universal in 


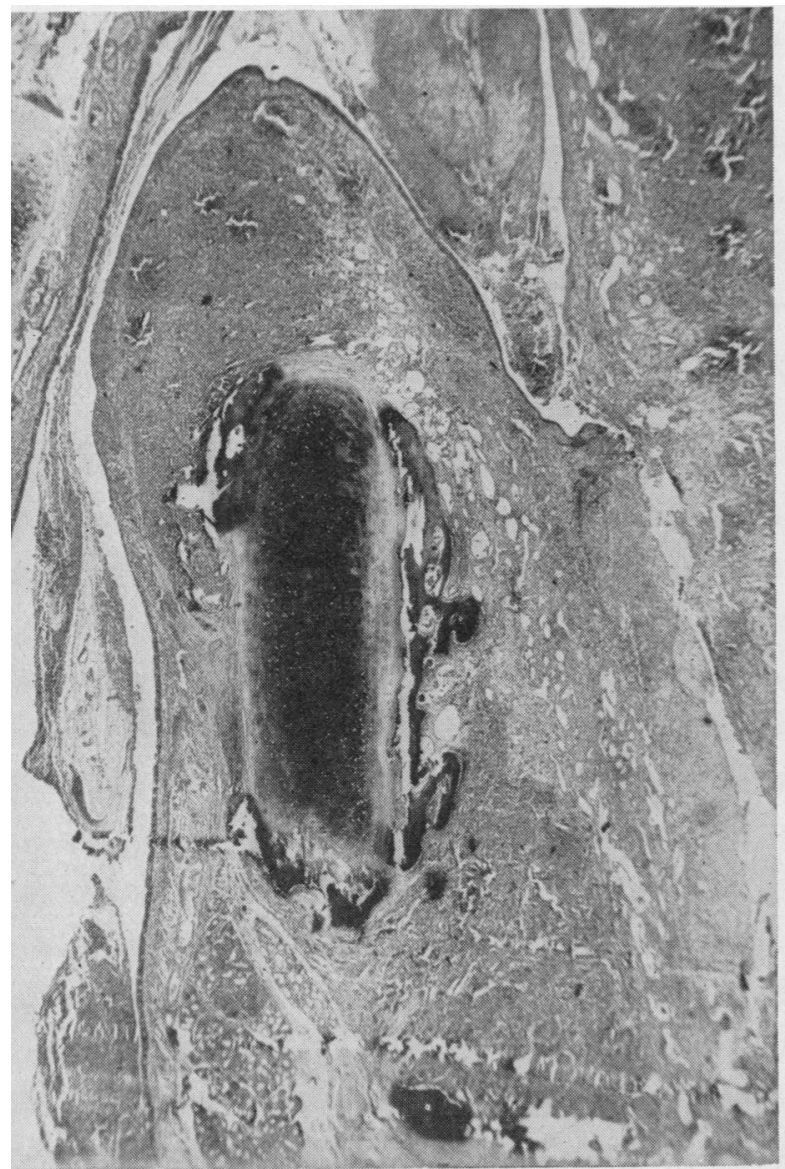

12.-Early ossification round bronchial cartilage in otherwise typical adenoma. Haematoxylin-eosin $\times 15$.

tumours that it can only be regarded as a factor in ossification when the tumour is slowly growing. The building of a network of mature bone requires time, and the bronchial adenoma is notoriously slow in its growth. In our Case 2, for example, the tumour was known to have been present for 20 years, and growth was further arrested by the insertion of radon seeds. Dukes (1939) emphasized the low-grade malignancy of his four bone-forming rectal carcinomas, but added that "the stimulus to osteogenesis seems to be provided by proliferating epithelium, so that metaplasia to bone-forming tissue may be attributed to the influence of certain types of epithelium on connective tissue."

The presence of bone in metastases (see Table III) confirms this view. It has been claimed that the tumour cells themselves exert a chemical or metabolic effect on the connective tissue (Laubmann, 1932 ; Scheidegger, 1939); and Willis has suggested that the bone-evoking property of prostatic carcinoma may be related to its phosphatase activity (Willis, 1953).

\section{Summary aNd CONClUSIONS}

Three cases of ossifying bronchial adenoma are described. Bone formation in tumours is due to a metaplasia of the stroma brought about by multiple factors. Its relative frequency in bronchial adenomas is due in part to slow growth, but principally to the presence of cartilage in or near the tumour. The cartilage undergoes necrosis and calcification and affords a convenient medium for ossification. Where distant metastases of malignant epithelial tumours are ossified, the metaplasia is probably due to a chemical influence exerted by the tumour cells themselves.

Our thanks are due to Sir Roy Cameron and Dr. J. W. Clegg for supplying microscopic sections of Cases 2 and 3 . Since this paper was written we have had the opportunity of examining material from two other ossifying bronchial adenomas, through the courtesy of Dr. Cameron Haight, of the University of Michigan, U.S.A. One of these had metastasized to a bronchial lymph node, but there was no bone formation in the metastasis.

\section{REFERENCES}

Belsey, R. H. R., and Valentine, J. C. (1951). J. Path. Bact., 63, 377.

Christie, A. C. (1951). Ibid., 63, 338.

Clark, A. (1935). Brit. J. Surg., $22,889$.

Dukes, C. E. (1939). Proc. roy. Soc. Med., 32, 1489.

Foster-Carter, A. F. (1941). Quart. J. Med., 10, 139.

Fried, B. M.(1948). Bronchogenic Carcinoma and Adenoma. Williams and Wilkins, Baltimore.

Gruber, G. B. (1913). Beitr. path. Anat., 55, 368.

Harvey, W. F., Dawson, E. K., and Innes, J. R. M. (1938). Edinb med. $J_{., 45}, 275$

Holley, S. W. (1946). Milit. Surg., 99, 528.

Josephy, H. (1925). Virchows Arch. path. Anat., $254,439$.

Kramer, R., and Som, M. L. (1935). Ann. Otol. (St. Louis), 44, 861.

- (1939). Arch. Otolaryng. (Chicago), 29, 356

Laubmann, W. (1932). Virchows Arch. path. Anat., 285, 169.

Leriche, R., and Policard, A. (1928). The Normal and Pathological Physiology of Bone. (Trans. by S. Moore and J. A. Key.) Mosby, St. Louis.

Mallory, T. B. (1941). New Engl. J. Med., 225, 983 (Case 27511).

Mayer, I. (1941). Frankfurt. Z. Path., 55, 548.

Micseh, G. (1933). Ibid., 44, 430.

Moersch, H. J., Tinney, W. S., and McDonald, J. R. (1945). Surg. Gyrtec. Obstet., 81, 551 .

Nicholson, G. W. (1917). J. Path. Bact., 21, 287.

(1924). Guy's Hosp. Rep., 74, 81 .

Pang, L. S. C. (1958). J. Path. Bact., 76, 357.

Reich, W. (1933). Z. Geburtsh. Gynäk., 104, 209.

Sano, M. E., and Meade, R. (1947). Arch. Path. (Chicago), 43, 235.

Santy, P., Galy, P., and Duprez, A. (1951). Bull. Soc. méd. Hôp. Paris, 67, 15 .

Scheidegger, S. (1939). Schweiz. Z. Path., 2, 153.

Schmorl, G. (1908). Verh. dtsch. path. Ges., 12, 89.

Schwenke, A. (1932). Z. Geburtsh. Gynäk., 103, 592

Senturia, H. R., Schechter, S. E., and Hulbert, B. (1948). Amer. J. Roentgenol., 60, 507.

Stout, A. P. (1943). Arch. Path. (Chicago), 35, 803

Thompson, J. R., Bosman, R. I., and Dumm, J. B. (1957). Dis. Chest 32, 463 .

Tudhope, G. R. (1939). J. Path. Bact., 48, 499.

van Patter, H. T., and Whittick, J. W. (1955). Amer. J. Path., 31, 73. Wessler, H., and Rabin, C. B. (1932). Amer. J. med. Sci., 183, 164. Willis, R. A. (1952). The Spread of Tumours in the Human Body, 2nd ed. Butterworth, London.

(1953). Pathology of Tumours, 2nd ed. Butterworth, London).

Womack, N. A., and Graham, E. A. (1938). Arch. Path. (Chicago, $26,165$. 